\title{
Spatial and temporal distribution of nitrate contents in the Mancha Oriental Hydro- geological System, SE Spain: 1998-2003
}

\author{
A. Moratalla ${ }^{1}$, J. J. Gómez-Alday ${ }^{2}$ \& J. de las Heras ${ }^{1}$ \\ ${ }^{I}$ Centro Regional de Estudios del Agua (CREA), \\ Universidad de Castilla-La Mancha (UCLM), Albacete, Spain \\ ${ }^{2}$ Grupo de Teledetección y SIG. Instituto de Desarrollo Regional (IDR), \\ Universidad de Castilla-La Mancha (UCLM), Albacete, Spain
}

\begin{abstract}
This project determines the nitrate content as well as spatial and temporal distribution in the water supply wells which extract groundwater from the Mancha Oriental System (MOS). The underground resources of the system are used in maintaining approximately 80,000 hectares of irrigation and are the water supply for a total population of 275,000 inhabitants. The average nitrate contents show a heterogeneous spatial distribution, varying between $0.1 \mathrm{mg} \mathrm{l}^{-1}$ and $125 \mathrm{mg} \mathrm{l}^{-1}$. The highest levels are associated with areas with large areas of irrigated crops. However, there are also points that are not found to be spatially linked to this type of farming in which nitrate has been detected in significant quantities. The presence of nitrate in these areas can be explained considering other sources of pollution or transport of the pollutant from contaminated areas through groundwater flow. In general, average nitrate values show a growing tendency during the period 1998 and 2003.

Keywords: nitrate, irrigated crops, groundwater, Mancha Oriental System, SE Spain.
\end{abstract}

\section{Introduction}

The natural quality of groundwater can be observed as altered by the presence of nitrate proceeding from farming and livestock activities. In fact, the excessive application of fertilizers has been admitted as the main cause of nitrate and other 
pollutants appearing in groundwater, [1-3]. In the European Union, Directives 91/676/CEE, 2000/60/CE, and 2006/118/CE consider polluted groundwater with nitrate content higher than $50 \mathrm{mg} \mathrm{l}^{-1}$.

Over the last 30 years, farming activities have grown significantly due to the extraction of water from the MOS: Irrigated crops have risen from 20,000 ha in 1982 to nearly 80,000 ha in the year 2003, according to Calera and Martín [4]. The representative crops grown in the area are corn, barley, wheat, sunflowers and alfalfa. These crops require high quantities of fertilizer and water to maintain elevated agricultural yield. In addition, groundwater within this system also represents the only resource supplying a total of 275,000 inhabitants spread throughout the provinces of Albacete and Cuenca.

The regional dependence on groundwater resources justifies undertaking studies on the origin, behavior and evolution of nitrate content found. In the MOS, De las Heras et al [5], study nitrate pollution in groundwater within the MOS during the years 1998 and 1999 and indicate a high presence of nitrate in irrigation water and the public water supply. The study concludes that certain irrigation practices linked to high output crops could be responsible for the high nitrate content found in several areas of the MOS.

In this study, groundwater used for the urban water supply has been sampled and the nitrate content has been determined along with spatial and temporal distribution for the years 1998, 1999, 2001 and 2003. Although, in general, the highest nitrogen content is associated with large irrigated areas, there are other points where the nitrate levels could be related to other sources of contamination. In addition, the nitrate present could have been transported from production areas through groundwater flow.

\section{Study area}

The MOS is located in the south east of the Region of Castilla-La Mancha, within the hydrographic catchment of the Júcar River Basin. This hydrogeological system comprises an area of 7,260 $\mathrm{km}^{2}$, Sanz et al [6].

Considering hydrogeology, the MOS can be considered a multiple-layered aquifer formed by the superposition of nine hydrogeological units (HU). The layers are of a diverse nature, belonging to the Triassic, Jurassic, Cretaceous, and Miocene period. The MOS is divided into six hydrogeological domains: Septentrional Domain (DS), Central Domain (DC), Salobral-Los Llanos Domain (DSL), Moro-Nevazos Domain (DMN), Pozo Cañada Domain (DPC), and Montearagón-Carcelén Domain (DMC), see Sanz et al [6] for further details.

The groundwater type within the study area is Calcium Bicarbonate (Table 1). This composition is related to the dissolution of the carbonate lithologies that are predominant in the aquifer HU.

The area climate is continental, semi-arid, with extreme temperatures in summer as well as winter. Average annual temperatures vary between $13^{\circ} \mathrm{C}$ and $14.5^{\circ} \mathrm{C}$. Precipitation is between $300 \mathrm{~mm}$ in the south and $550 \mathrm{~mm}$ in the northern MOS. 
Table 1: General characteristics of groundwater (782 samples, years 1998, 1999, 2001 and 2003).

\begin{tabular}{|c|c|c|c|c|}
\hline Variable & Average & Min. & Max. & S.D. \\
\hline $\mathrm{NO}^{3-}\left(\mathrm{mg} \mathrm{l}^{-1}\right)$ & 24.1 & 2.6 & 116.2 & 18.7 \\
\hline $\mathrm{HCO}^{3-}\left(\mathrm{mg} \mathrm{l}^{-1}\right)$ & 321.4 & 130.9 & 603.6 & 75.7 \\
\hline $\mathrm{Cl}^{-}\left(\mathrm{mg} \mathrm{l}^{-1}\right)$ & 39.1 & 5.2 & 171.4 & 30.4 \\
\hline $\mathrm{SO}^{4-}\left(\mathrm{m} \mathrm{l}^{-1}\right)$ & 127.5 & 4.3 & 634.1 & 121.4 \\
\hline $\mathrm{Ca}^{2+}\left(\mathrm{mg} \mathrm{l}^{-1}\right)$ & 96.5 & 24.0 & 218.0 & 32.7 \\
\hline $\mathrm{Mg}^{2+}\left(\mathrm{mg} \mathrm{l}^{-1}\right)$ & 47.3 & 4.0 & 145.0 & 25.9 \\
\hline $\mathrm{Na}^{+}\left(\mathrm{mg} \mathrm{l}^{-1}\right)$ & 15.4 & 1.8 & 122.5 & 16.0 \\
\hline $\mathrm{K}^{+}\left(\mathrm{mg} \mathrm{l}^{-1}\right)$ & 1.7 & 0.1 & 15.1 & 2.4 \\
\hline
\end{tabular}

The largest river crossing the hydrogeological area is the Júcar River. The Valdemembra, Arroyo Ledaña and Cabriel Rivers are affluents of the Júcar on the left side.

\section{Methodology}

A total of 782 groundwater samples were collected in 57 sampling events from urban water supplies located throughout the three hydrogeological domains of the MOS (Fig. 1). Each point has been sampled every trimester during the years 1998, 1999, 2001 and 2003. Data is not available in the DS for 1998. In this domain only one sample point was analyzed in 1999. The nitrate content in each sample was determined using the ionic chromatography technique APHA [7].

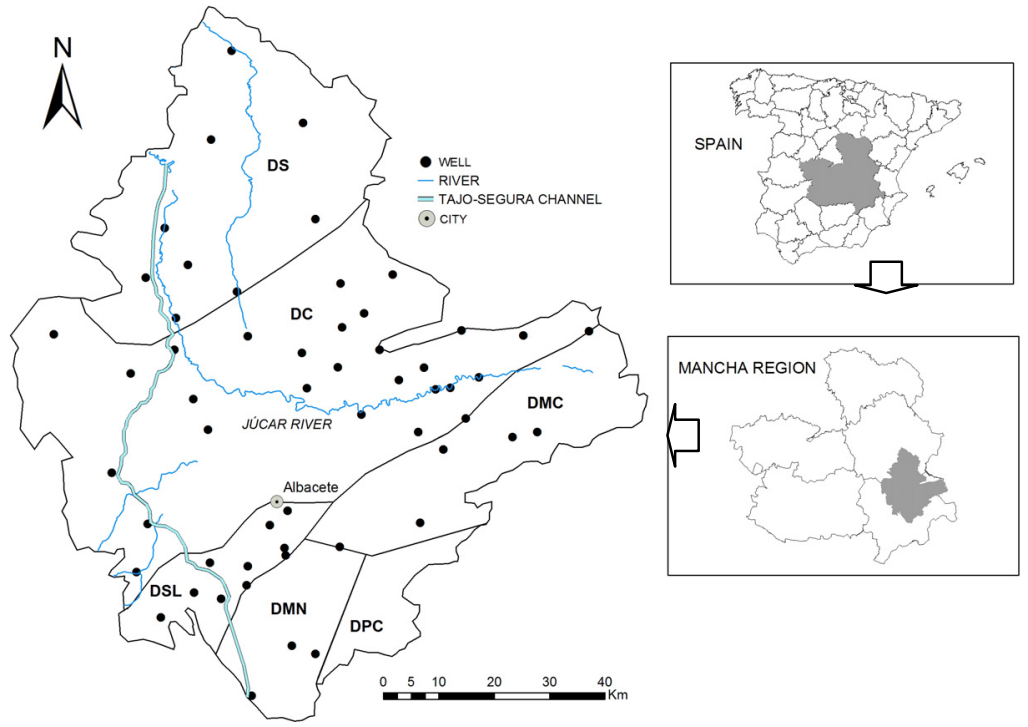

Figure 1: Study area and location of the sampled wells. 
The maps of nitrate distribution and irrigated surfaces were obtained using the ArcMap 8.2 software (ESRI). The data on irrigated areas come from the GIS and Teledetection Group from the IDR at UCLM. In order to obtain the spatial distribution of nitrate content (Fig. 2), the method "inverse distance weighted" (IDW) was used.

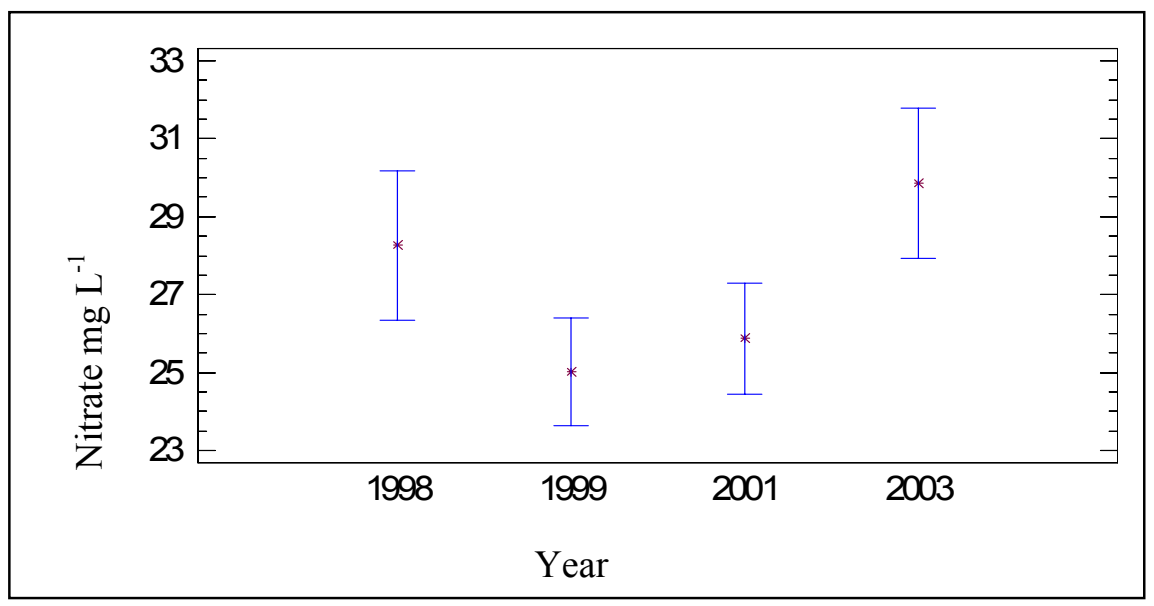

Figure 2: Nitrate content means and 95\% intervals LCD.

\section{Nitrate contents in groundwater}

Analytical results indicate significant differences in average nitrate concentration depending on the domain considered, although none exceed the admissible maximum quantity $\left(50 \mathrm{mg} \mathrm{l}^{-1}\right)$. The highest average content is found in DC and DSL. In DC, nitrate concentrations are between $0.1 \mathrm{mg} \mathrm{l}^{-1}$ and $125 \mathrm{mg} \mathrm{l}^{-1}$ (Mean value: $29.7 \mathrm{mg} \mathrm{l}^{-1}$ ) (Fig. 3; Table 2). In DSL, nitrate concentration values vary between $11.7 \mathrm{mg} \mathrm{l}^{-1}$ and $61.4 \mathrm{mg} \mathrm{l}^{-1}$ (Mean value: $26.3 \mathrm{mg} \mathrm{l}^{-1}$ ). The domains DS (Mean value: $15.2 \mathrm{mg} \mathrm{l}^{-1}$ ), DPC (Mean value: $17.8 \mathrm{mg} \mathrm{l}^{-1}$ ), DMN (Mean value: $18.6 \mathrm{mg} \mathrm{l}^{-1}$ ), and DMC (Mean value: $22.3 \mathrm{mg} \mathrm{l}^{-1}$ ) have lower values present (Fig. 3; Table 2).

The analysis of the temporal evolution of values yields results indicating a decrease between 1998 and 1999 in average nitrate concentration in all domains considered. This tendency was also found in the study by De las Heras et al [5]. However, after 1999 a progressive increase in nitrate presence was found in groundwater. 


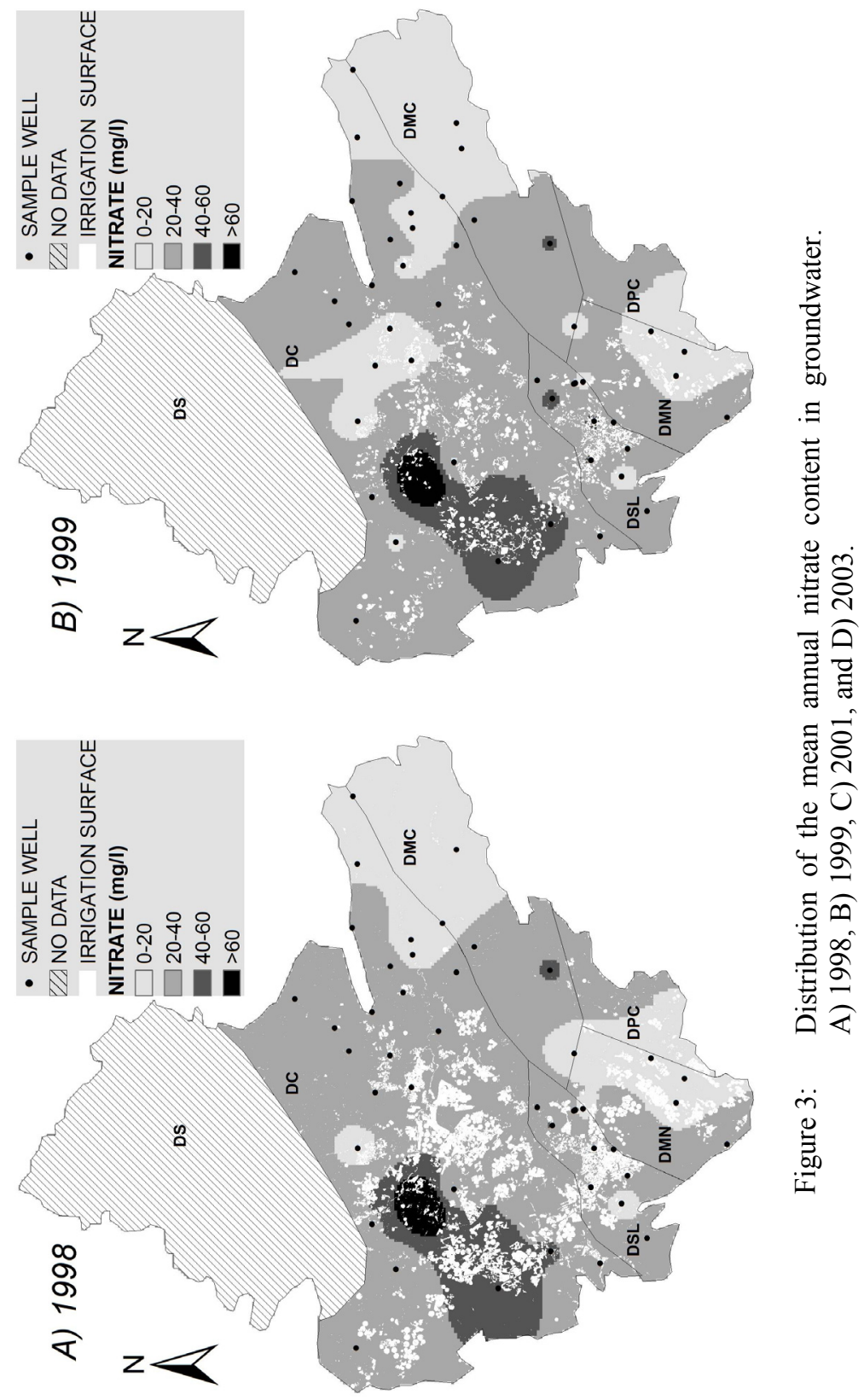



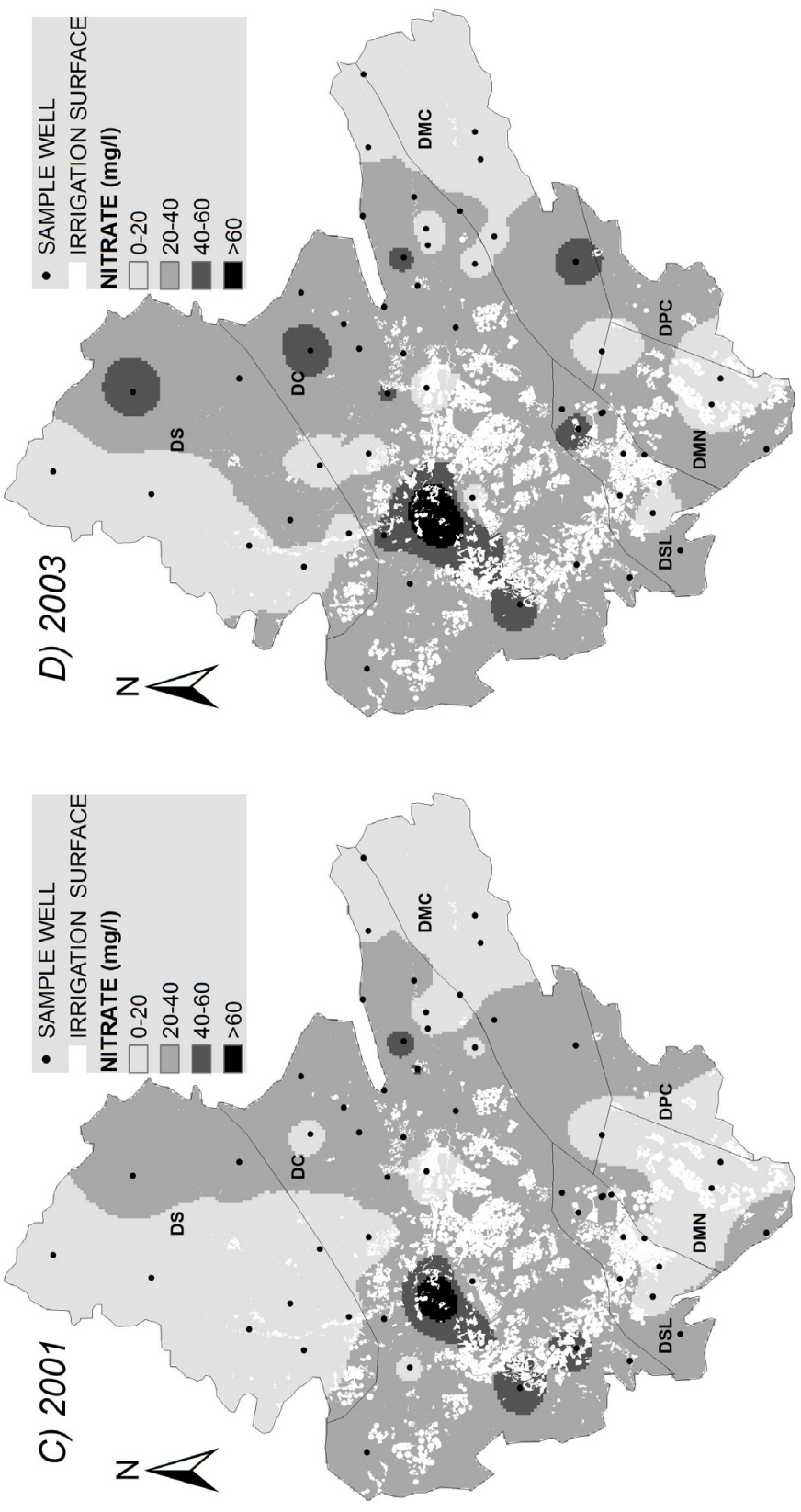

言

$\ddot{0}$
$\stackrel{0}{\sigma}$
$\ddot{D}$ 
Table 2: $\quad$ Basic statistics of the nitrate contents ( $\mathrm{n}=$ number of samples).

\begin{tabular}{|c|c|c|c|c|c|}
\hline \multicolumn{6}{|c|}{ Septentrional Domain } \\
\hline & $\mathbf{n}$ & Mean & Minimum & Maximum & S.D. \\
\hline 2001 & 16 & 13.2 & 9.1 & 29.4 & 5.7 \\
\hline 2003 & 30 & 16.3 & 6.8 & 61.9 & 12.6 \\
\hline Total & 47 & 15.2 & & & \\
\hline \multicolumn{6}{|c|}{ Central Domain } \\
\hline 1998 & 74 & 31.1 & 1.5 & 125.0 & 19.3 \\
\hline 1999 & 133 & 26.9 & 0.9 & 122.0 & 16.6 \\
\hline 2001 & 168 & 28.4 & 0.1 & 107.1 & 17.4 \\
\hline 2003 & 73 & 36.8 & 5.6 & 124.1 & 21.6 \\
\hline Total & 448 & 29.7 & & & \\
\hline \multicolumn{6}{|c|}{ Montearagón-Carcelén Domain } \\
\hline 1998 & 5 & 30.7 & 5.0 & 42.0 & 15.3 \\
\hline 1999 & 16 & 19.8 & 4.3 & 43.2 & 14.1 \\
\hline 2001 & 22 & 21.5 & 0.4 & 56.2 & 17.7 \\
\hline 2003 & 11 & 28.2 & 2.6 & 52.4 & 18.9 \\
\hline Total & 54 & 22.3 & & & \\
\hline \multicolumn{6}{|c|}{ Pozo Cañada Domain } \\
\hline 1998 & 5 & 19.8 & 16.4 & 22.9 & 3.1 \\
\hline 1999 & 9 & 16.8 & 14.4 & 20.4 & 2.2 \\
\hline Total & 14 & 17.8 & & & \\
\hline \multicolumn{6}{|c|}{ Moro-Nevazos Domain } \\
\hline 1998 & 8 & 20.6 & 14.1 & 26.4 & 3.9 \\
\hline 1999 & 18 & 14.7 & 10.3 & 24.9 & 3.9 \\
\hline 2001 & 18 & 20.6 & 9.9 & 34.1 & 8.6 \\
\hline 2003 & 6 & 22.00 & 10.4 & 33.1 & 10.7 \\
\hline Total & 50 & 18.6 & & & \\
\hline \multicolumn{6}{|c|}{ Salobral-Los Llanos Domain } \\
\hline 1998 & 45 & 26.8 & 14.0 & 49.4 & 8.9 \\
\hline 1999 & $\begin{array}{l}88 \\
\end{array}$ & 26.3 & 12.4 & 48.1 & 9.4 \\
\hline 2001 & 21 & 24.7 & 12.8 & 41.5 & 9.1 \\
\hline 2003 & 15 & 27.4 & 11.7 & 61.4 & 11.9 \\
\hline Total & 169 & 26.3 & & & \\
\hline
\end{tabular}

\section{Spatial and temporal distribution of nitrate contents in the MOS}

Nitrate content in groundwater is distributed in a heterogeneous fashion throughout the MOS (Fig. 3). The areas of highest annual means of nitrate concentrations are associated with the DC and DSL domains, which both sustain large areas of irrigated cultivation. Agricultural activities have been admitted to be potential sources of nitrate pollution due to extensive application of inorganic fertilizers [8-11].

Nevertheless, some samples in the DS and DMC domains with nitrate concentrations higher than the permitted levels are not spatially associated with irrigated crops (Fig. 3). This fact suggests that the origin of nitrate could be associated with sources other than farming, such as urban or industrial waste, or waste from livestock activities. Another possible explanation would be that 
groundwater can transport nitrate from point sources of pollution to other areas of the MOS where potential polluting activities are nonexistent. In order to collect data supporting this hypothesis, additional studies are required to further investigate the spatial and temporal evolution of nitrate concentrations and the relationship with the flow regime of the hydrogeological system (e.g. aquiferriver relation).

\section{Conclusions}

The MOS groundwater presents elevated nitrate content, which can reach maximum values of $125 \mathrm{mg} \mathrm{l}^{-1}$. Significant differences have been found within the different domains considered. The average maximum values were detected in DC (29.7 $\left.\mathrm{mg} \mathrm{l}^{-1}\right)$ and DSL $\left(26.3 \mathrm{mg} \mathrm{l}^{-1}\right)$. The minimum values were found in DS (15.2 $\left.\mathrm{mg} \mathrm{l}^{-1}\right)$. Nitrate presence in the MOS groundwater decreases within the period 1998-1999 and increases within the period 1999 and 2003.

The maximum values correspond to the most extensive irrigated farmed areas (DC and DSL). The source of nitrate in these domains can be associated with the use of inorganic fertilizers applied to irrigated crops. Nevertheless, there are areas where the irrigated area is practically zero, as in DS and DMC, where average nitrate content was also relatively high. In these areas, the nitrate present could be related to other inputs or may have been transported from the source of pollution by groundwater flow.

\section{Acknowledgements}

This project has been funded by several research agreements between CREAUCLM and the Committee of the Communities of Castilla-La Mancha and the Albacete City Council. The authors would like to thank Dr. Pilar Mañas and Elena Castro, researchers at CREA, for their support in performing the field work. We also give our thanks to Dr. David Sanz from the GIS and Teledetection group at IDR for his technical support and consultation.

\section{References}

[1] Follet, R. F., Nitrogen Management and Ground Water Protection, Elsevier Science Publishers B.V: Amsterdam, The Netherlands, 1989.

[2] Kladivko, E.J., Van Scoyoc, G.E., Monke, E.J., Oades, K.M. \& Pask, W., Pesticida and nutrient movement into subsurface tile drains on a silt loam soil in Indiana. Journal of Environmental Quality, 20, pp. 264-270, 1991.

[3] Keeney, D.R. \& De Luca, T.H., Des Moines River nitrate in relation to watershed agricultural practices: 1945 versus 1980's. Journal of Environmental Quality, 22, pp. 267-272, 1993.

[4] Calera, A. \& Martín F., Uso de la teledetección en el seguimiento de los cultivos de regadío (Chapter XIV). Agua y Agronomía, ed. Mundi Prensa: Madrid, Barcelona, México, pp. 523-583, 2005. 
[5] De Las Heras, J., Castro, E., Mañas, P., Sánchez-Vizcaíno, J., Sánchez, J.C. \& Mejías, M., Groundwater Quality and Nitrate Pollution of 08-29 Hydrogeological Unit Mancha Oriental, Spain. Journal of Balkan Ecology, 4, pp. 434-444. 2001.

[6] Sanz, D., Martínez-Alfaro, P.E., Castaño, S. \& Gómez-Alday, J.J., Caracterización de los dominios hidrogeológicos individualizados en el Sistema Mancha Oriental. SE Español. Geogaceta, 38, pp. 251-254, 2005.

[7] APHA, Standard methods for the examination of water and wastewater. American Public Health Association, Washington D.C., 1989.

[8] González, J.C., Grande, J.A., Barragán, F.J., Ocaña, J.A. \& De La Torre, M.L., Nitrate Accumulation and Other Components of the Groundwater in Relation to Cropping System in an Aquifer in Southwestern Spain. Water Resources Management 19, pp. 1-22, 2005.

[9] Helena B., Vega M., Barrado E., Pardo R. \& Fernández L., A case of hydrochemical characterization of an alluvial aquifer influenced by human activities. Water, Air and Soil Pollution 112, pp. 365-387, 1998

[10] Schepers, J.S., Varvel, G.E. \& Watts, D.G., Nitrogen and water management strategies to protect groundwater quality. Trans. World Cong. Soil Sci. 5, pp. 192-204, 1994.

[11] Richards, R., Baker, D., Creamer, N., Kramer, J., Ewing, D., Merryfield, B. \& Wallrabenstein, L., , 'Well water quality, well vulnerability, and agricultural contamination in the Midwestern United States', Journal of Environmental Quality, 25, pp. 389-402, 1996. 